Ty

Working Papers

\title{
272
}

\section{Involuntary temporary and part-time work, job quality and well-being at work}

Merja Kauhanen

Jouko Nätti 


\title{
272
}

Involuntary

temporary and

part-time work,

job quality and

well-being at

work*

\author{
Merja Kauhanen** \\ Jouko Nätti***
}

*This paper is part of the project "Between employment and unemployment. Involuntary part-time and temporary work in Nordic countries: extent, explanations, transitions and well-being outcomes' funded by the Academy of Finland. We are grateful for this financial support. We are also grateful for participants of IWPLMS Conference in Tampere and Work, Employment \& Society Conference in Brighton for comments.

**Labour Institute for Economic Research, Helsinki

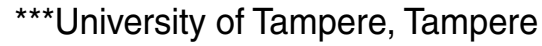


TYÖPAPEREITA 272

DISCUSSION PAPERS 272

Julkaisija:

Palkansaajien tutkimuslaitos

Pitkänsillanranta 3 A, 00530 Helsinki

www.labour.fi

ISBN 978-952-209-098-0

ISSN 1795-1801 


\title{
TIIVISTELMÄ
}

Tässä tutkimuksessa tarkastellaan työsuhteen tyypin merkitystä työpaikkojen laatuun käyttäen suomalaisia työolotutkimusten aineistoja vuosilta 1997, 2003 ja 2008. Työsuhteet on jaettu eri tyyppeihin huomioiden myös syy määräaikaisen ja osa-aikaisen työn tekemiseen. Tulosten mukaan työpaikkojen laadussa löytyy selviä eroja työsuhteen tyypin mukaan. Tulokset osoittavat myös, kuinka tärkeää on erottaa vastentahtoisesti määrä- ja osa-aikaista työtä tekevät muista syistä näitä työsuhteita tekevistä näissä tarkasteluissa. Vastentahtoisten määrä- ja osa-aikaisten palkansaajien arviot olivat lähes poikkeuksetta heikompia tässä paperissa tutkittujen keskeisten työn laatua kuvaavien indikaattorien suhteen kuten koulutusmahdollisuudet, osallistuminen työnantajan maksamaan koulutukseen, etenemismahdollisuudet, kehittymismahdollisuudet, vaikutusmahdollisuudet työssä ja koettu työn epävarmuus.

Avainsanat: vastentahtoinen, määräaikainen työ, osa-aikatyö, työpaikkojen laatu

\begin{abstract}
This paper studies the impact of job contract types on perceived job quality using Finnish 2008 Quality of Work Life Surveys from years 1997, 2003 and 2008. In the analysis job contract types are adjusted to take into account the motive for doing temporary and part-time work. Our results from the Finnish QWLS imply that there are clear differences in job quality and work well-being by the type of job contract. Our results also show the importance of distinguishing between types of temporary and part-time work by the contract preference, i.e. whether these nonstandard employment arrangements are exercised involuntarily or not. Almost without exception involuntary temporary and involuntary part-time workers' experiences of their job quality are weaker with respect to core job quality indicators studied in this paper such as training possibilities, participation in employer-funded training, career possibilities, possibilities to learn and grow at work, job autonomy, and job insecurity.
\end{abstract}

Keywords: involuntary, temporary work, part-time work, quality of jobs

JEL Classification: J24, J81 


\section{INTRODUCTION}

Job quality has been one of the overarching objectives of the European Union growth and job strategy over a decade. In the strategy the objective has been to create not only more jobs but also better jobs. Why job quality and worker well-being matters? The earlier literature has shown that worker's job quality has profound consequences for his or her psychological, social and economic wellbeing (Kalleberg and Vaisey, 2005). In the literature a clear-cut link has also been shown to exist between job quality and productivity (e.g. Zelenski et. al., 2007; Buhai et al., 2008). Job quality may be a production factor able to increase the wealth of regions (Royuela and Suriñach, 2008). According to The European Working Conditions Survey (The European Foundation for the Improvement of Living and Working Conditions ${ }^{1}$, 2008) job quality and working conditions affect retirement decisions and job quality is a key factor that makes workers stay longer in the working life which is an important policy objective in ageing societies.

At the same time as the importance of job quality and worker well-being has been increasingly recognised as an important policy objective, an increased use of nonstandard job contracts such as use of temporary job arrangements has caused a general concern in the public opinion about the perceived 'erosion' in the quality of jobs (European Commission, 2008). Deepening of globalisation, an increased competition, accelerated technological change, and ageing work force have put pressures on the ability of labour market to adapt to the changing environment. Full-time open-ended contracts have in many western countries given way to more atypical and flexible forms of employment such as part-time and temporary employment, which makes it easier for firms to adjust to changing demands and economic fluctuation. Changes in the shares of temporary and parttime jobs both have indicated a long-term upward trend in Europe (European Commission, 2009). These structural changes in the labour market and the increased use of nonstandard job arrangements have raised concern that they are worse for workers than 'standard' contracts, i.e. permanent and full-time jobs (Blank, 1998; Kalleberg et al., 1999; European Commission, 2008).

Whether the growth of nonstandard employment is problematic depends on the quality of these nonstandard jobs (Kalleberg et al., 1999). There is empirical evidence from different countries of the less-favourable treatment of temporary and part-time workers compared to permanent and full-

\footnotetext{
${ }^{1}$ Later in this paper referred to as Eurofound.
} 
time workers ${ }^{2}$ as regards the quality of their jobs in that they often have lower job security, reduced access to both statutory and employer-provided social security benefits, and disadvantages in access to firm-funded training (e.g. Eurofound 2003; De Graaf-Zilj, 2005; Leschke 2007; Kauhanen, 2009). However, in this literature much less attention has been paid to the differences that there might exist inside the groups of temporary and part-time workers with regard to their job quality although we know that these groups are very heterogeneous in many respects (Kauhanen, 2007). One important division might be here whether these nonstandard employment arrangements are exercised involuntarily or not (Eurofound, 2008). In the psychological literature there have been found differences in job satisfaction and health outcomes by the contract preferences. For example, Krausz et al. (2000) found with Canadian data that voluntary temporary help employees were more satisfied and involved, and less stressed compared to involuntary temporary help employees. Isaksson and Bellagh (2002) found that contract preferences appeared to be negatively related to both health outcomes (distress and somatic complaints), and the relation was mediated by perceptions of work load and social support. Typically these studies making difference between preferred and non-preferred job arrangements have focused on temporary or temporary agency contracts and not on part-time work.

This paper contributes to the earlier literature by investigating whether there exist differences in the job quality of involuntary temporary and part-time workers in comparison to other temporary and part-time workers and regular full-time workers. Involuntariness refers to workers stating as the reason for temporary or part-time work that they could not find a permanent or full-time job. In our analysis we focus on the following core dimensions of job quality: the availability of opportunities for skills development (including possibilities for training, participation in employer-funded training, possibilities to learn and grow at work, career opportunities), job autonomy and task discretion, and job insecurity shown to be central to the notion of job quality.

The other contribution is that we are also able to study development and trends of job quality among these groups over a longer period of time, in practise from 1997 to 2008. Typically in many studies on job quality the data covers only a shorter period of time/is cross-sectional which does not

\footnotetext{
${ }^{2}$ Of these problems related to unequal treatment also tells that in the EU both Fixed-term Work and Part-time Work Directives (1999/70/EC, 1997/81/EC and 1998/23/EC) have been drawn up in order to end less favourable treatment of temporary and part-time workers, and increase the quality of these jobs. Furthermore, the directive supports the increase of voluntary part-time work and flexible working time arrangements, which take into account the needs of both employees and employers. The aim is that temporary and part-time employees would be equally treated than similar permanent and full-time workers (apart from issues of pay) unless there is an objective reason to justify the less favourable treatment.
} 
make it possible to study the trends in job quality across time. In addition, in the analyses we use statistical models where we can study the relative importance of the type of employment arrangement on perceived job quality outcomes which purely descriptive analyses are not able to do.

We study the impact of the type of job contract adjusted for the reason on job quality and worker well-being with the Finnish data. In Finland over quarter of all wage and salary workers (25.5 percent in 2010) work either in temporary and part-time jobs and the shares of both involuntary temporary and part-time employment are quite high in Finland even internationally compared (Leschke and Watt, 2008). In 2010 on average 64 percent of temporary employees and 26 percent of part-time employees worked on involuntary basis in Finland because they had not been able to find a permanent or a full-time job.

The structure of the paper is as follows. Section 2 deals with how job quality and well-being at work have been measured in the literature. Section 3 introduces the data and provides descriptive statistics. Section 4 presents methods and section 5 the results. Finally section 6 summarises and discusses the main findings of the paper.

\section{HOW TO MEASURE JOB QUALITY?}

According to Green (2006) the quality of work life or job quality is constituted by the set of work features which foster the well-being of the worker. Well-being at work is therefore closely connected with the concept of job quality and the related literature. Job quality is a complex concept to measure and include many dimensions which shows well in the variety of frameworks and of key indicators of job's and workers' characteristics used in the literature for the evaluation of job quality. There is either no consensus in the literature which criteria and which key indicators should be used to describe to evaluate job quality and well-being at work, although the variety of different frameworks and key indicators also overlap and bear resemblance to each other.

The variety of frameworks used in measuring job quality is illustrated in the following examples. EuroFound (2002) has proposed analytical framework to be used in the evaluation of job and employment quality which has four main dimensions i) career and employment security, ii) health and well-being of workers, iii) skills development, and iv) reconciliation of working and nonworking life. 
Figure 1. Framework to evaluate quality of work and employment (Eurofound, 2002).

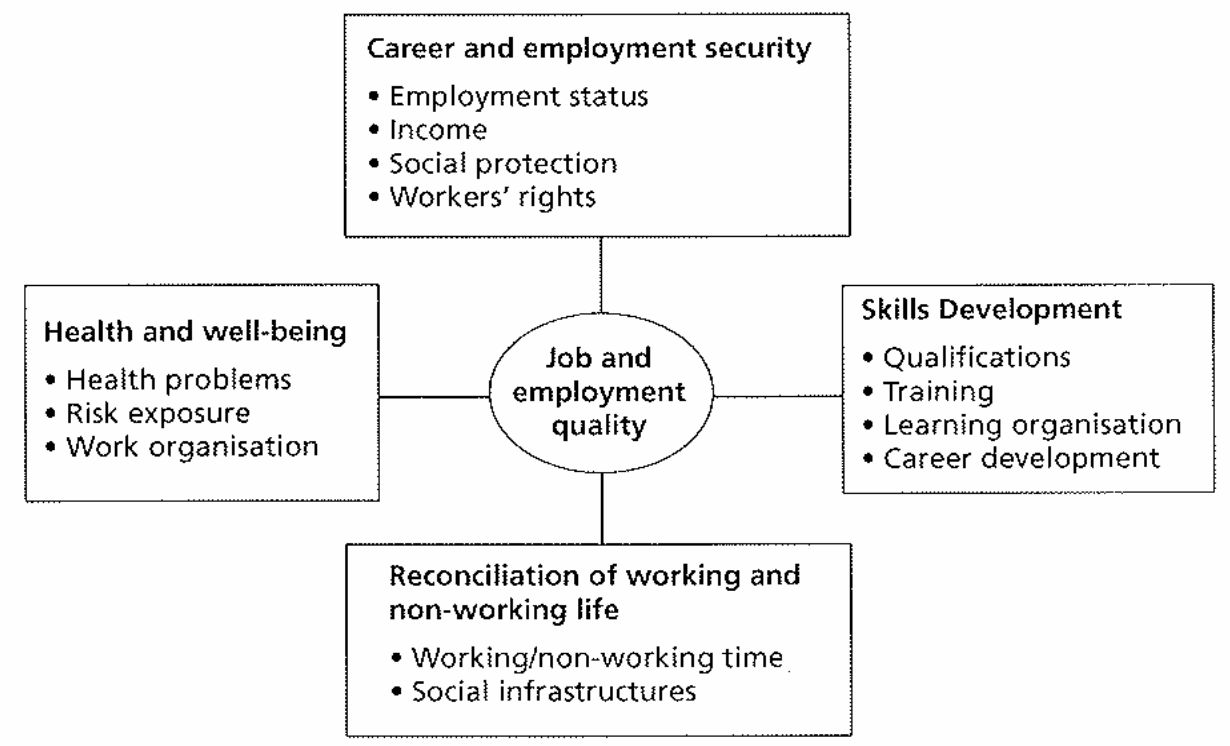

Related to evaluation of job quality, International Work Organization (ILO) has launched a concept of decent work which includes four objectives: i) the promotion of labour rights, ii) employment, iii) social protection, and iv) social dialogue. In the EU a broad concept of job quality including ten dimensions with corresponding indicators (so called Laeken indicators) to measure each of these dimensions was adopted in 2001 (for a full list see European Commission, 2008). These indicators include not only indicators related to the job characteristics itself and its quality (e.g. intrinsic job quality, skills and lifelong learning) but also measures related to the wider labour market context such as social dialogue and workers' involvement and overall economic performance and productivity. In addition, often cited list of key indicators of job quality is also by Green (2006) in which the following aspects of a job are regarded as the core indicators: i) wages (including fairness of wages), ii) the skills involved in a job (including lifelong learning and career development), iii) autonomy/discretion over job tasks, iv) work effort, and v) low risks and security (employment security and physical security).

It is increasingly common to combine both objective and subjective approaches in the measurement of job quality. This partly reflects the prevailing development in the economic literature where subjective measures of well-being such as life satisfaction and happiness have been increasingly used to evaluate an individual's utility (see Frey and Stutzer, 2002). Including also subjective measures such as job satisfaction provides a broader picture of job quality and well-being at work compared to using only a more traditional concept of utility and objective measures such as wages and hours of work. Closely related to the results received in the economics of happiness literature is 
the notion of procedural utility, which means that people do not care only about the outcomes such as pay and hours of work, but also about the conditions and processes leading to such outcomes (European Commission, 2008; Frey and Stutzer, 2004). Green (2006) points out that as the pivotal components of job quality are primarily measurable through the evaluations of the workers in the surveys, any comprehensive measure is affected by the potential limitations (e.g. social esteem bias) as well as the advantages (e.g. first-hand knowledge) of subjective data.

\section{DATA AND DESCRIPTIVE STATISTICS}

We use extensive face-to-face interview surveys among the working-age population in Finland, The Quality of Work Life Surveys (QWLS), from years 1997, 2003 and 2008 to investigate the consequences of involuntary temporary and involuntary part-time work from the perspective of job quality and well-being at work in the Finnish labour market. The Quality of Work Life Surveys are based on personal face-to-face interviews of 15-64-year-old wage and salary earners selected by a random draw from the Finnish labour force survey. Therefore they provide a representative sample of the Finnish wage and salary earners. The sizes of the random sample were as follows: 3,800 wage and salary earners in 1997, 5,300 wage and salary earners in 2003 and 6,499 wage and salary earners in 2008. The participation rates in these surveys have been high; i.e. 79 percent in 1997, 78 percent in 2003, and 68 percent in 2008.

The Quality of Work Life Surveys suit excellently for investigating job quality due to their rich data content including both objective and subjective indicators of job quality. Besides describing the physical, mental and social work environments, the data also depict the contents of work, employees' labour market positions, conditions of employment, values and valuations of work and factors at the work organisation level. In addition, an advantage of the data is that the survey questions have remained similar across the years and therefore provide a useful database to study changes in the working life such as job quality across time (see Lehto and Sutela, 2008).

As comparison groups to involuntary temporary and part-time workers we use other temporary and part-time workers ${ }^{3}$, and permanent, full-time workers. Table 1 in the appendix describes the basic characteristics of these comparison groups for pooled data and years 1997, 2003 and 2008

\footnotetext{
${ }^{3}$ The group other temporary employment and the group other part-time employment are residuals and include all other types of temporary employment and part-time employment. In the analyses we use mutually exclusive groups. Therefore workers working at the same time as part-timer in a temporary job are excluded from our analysis.
} 
separately. Majority of workers in either involuntary or other temporary and part-time jobs are women, whereas their share is around 50 percent among permanent and full-time workers. It is noteworthy that among involuntary temporary and part-time workers the shares of women are even higher compared to other temporary and part-time workers. By age part-timers and permanent, fulltime workers are on average slightly older than other groups.

Part-timers have the largest shares of workers with primary education only. In contrast, the highest shares of workers with tertiary education are among permanent and full-time workers and among temporary workers. By socio-economic status the greatest shares of blue-collar workers are found in the group of permanent and full-time workers and in the group of involuntary part-timers.

Differences can also be detected by the total time in working life. On average, temporary workers have the shortest time in working life (average around 10-12 years ${ }^{4}$ ) and longest in permanent and full-time jobs (average around 22 years). It is noteworthy that changes have taken place in the characteristics of all groups over the years such as rise in the educational level.

The QWLS surveys ask about the workers' skills development possibilities with following questions: i) In your current workplace do you have good, fair or poor opportunities for receiving training to improve your professional skills?, ii) Over the last 12 months, have you attended courses paid by the employer?, iii) In your current workplace, are your advancement opportunities good, fair or poor? and, iv) In your current workplace, are your opportunities to learn and grow at work (i.e. self-development) good, fair or poor? Job autonomy/task discretion is asked with the following questions: Are you able to influence a lot, quite a lot, a little or not at all the contents of your tasks, the order in which you do your tasks, your working methods, the division of tasks between employees, choice of your working partners? In our analyses we use a summary variable which includes these six dimensions of job autonomy ${ }^{5}$. The reliability of this variable is reasonably good (Cronbach's alpha=0.804). The QWLS surveys ask about job security among others with the following questions: Does your work carry any of the following insecurity factors: Threat of dismissal? Threat of unemployment? In our analyses we use the latter one. The averages of selfreported job quality indicators we use in our estimations are reported in Table 2 in the appendix.

\footnotetext{
${ }^{4}$ The average from the year 1997 is lower.

${ }^{5}$ This summary variable have been reclassified into three categories on the basis of average scores, where average scores $>=3$ and $<=4$ denote good job autonomy, mean scores between 2 and 3 denote in between and values $>=1$ and $<=2$ denote bad job autonomy.
} 


\section{METHODS}

We investigate the impact of type of job contract on different job quality outcomes using ordered probit regressions in cases where our self-reported indicator of job quality is ordinal ${ }^{6}$ :

$$
Y_{i}^{*}=\beta \mathrm{X}_{\mathrm{i}}+\delta \mathrm{JTYPE} \mathrm{i}_{\mathrm{i}}+\varepsilon_{\mathrm{i},} \varepsilon_{\mathrm{i}} \sim \mathrm{N}(0,1)
$$

$\mathrm{Y}_{\mathrm{i}}{ }^{*}$ is the latent outcome variable of job quality for individual $\mathrm{i}$ and takes three possible values: $1=$ poor, $2=$ fair, $3=$ good as regards following job quality dimensions: training possibilities, career opportunities, opportunities to learn and grow at work.

We do no observe $\mathrm{Y}_{\mathrm{i}}{ }^{*}$ but only the ordered categorical variable

$$
\begin{aligned}
Y_{i} & =1 \text { if } Y_{i}^{*} \leq \gamma_{1} \\
& =2 \text { if } \gamma_{1} \leq Y_{i}^{*}<\gamma_{2} \\
& =3 \text { if } \gamma_{2} \leq Y_{i}^{*}
\end{aligned}
$$

where $\gamma_{1}$ and $\gamma_{2}$ are the unknown cut points that must be estimated. $X_{i}$ is the vector of covariates which include both individual-specific characteristics (e.g. gender, age, education and socioeconomic status) and individual's job-specific characteristics (e.g. size of the firm, industry and sector) and $\beta$ is the vector of coefficients associated with the X. JTYPE $E_{i}$ is the job contract type adjusted for reason for temporary and part-time work (i.e. permanent and full-time, involuntary temporary, other temporary, involuntary part-time and other part-time). $\varepsilon_{\mathrm{i}}$, is the random error term $\sim \mathrm{N}(0,1)$.

In ordered probit regressions the sign of the regression parameters can be interpreted as determining whether the latent variable ${ }^{7}$ increases with the independent variable or not (see e.g. Green, 1997). If the coefficient is positive, an increase in the regressor decreases the probability of being in the lowest category ('poor' in our case) and increases the probability of being in the highest category ('good' in our case).

\footnotetext{
${ }^{6}$ Otherwise we use binary probit regressions.

${ }^{7}$ Ordinal variables are usually seen as observable indicator variables of underlying latent continuous variables.
} 


\section{RESULTS}

The results for job quality outcomes from pooled ordered probit/probit regressions are reported in Tables 3 and 4 in the appendix.

\section{Opportunities for skills development}

Skills development has been regarded as one of the core dimensions of job quality in the literature given the importance of skills for employees' life chances (Gallie, 2008; Kalleberg et al., 1999). In the literature it is well established that past work-related training is associated with higher wages (e.g. Mincer 1989, Bishop 1996). Skills development has also been combined with organisations' productivity and performance.

The estimated effects of the job contract type on skills development indicators (i.e. perceived training possibilities, career prospects and possibilities to learn and grow at work, participation in employer-funded training) are presented in Table 3 (columns 3A-3C) and in the first column of Table 4. According to our results the type of job contract matters for workers' skills development opportunities. There also exists heterogeneity in perceived skills development opportunities by the motive for temporary and part-time work. Involuntary temporary, involuntary part-time and other part-time workers show statistically significantly lower probabilities of having higher values of training possibilities, career prospects and possibilities to learn and grow at work compared to permanent and full-time workers (scale from 1 to 3 , where $1=$ poor and 3 =good). For other temporary workers the difference is not statistically significant. Workers in temporary and part-time job contracts including other temporary workers have a lower probability of employer-funded training compared to permanent and full-time workers.

In order to clarify the interpretation of the results, we also present predicted probabilities for positive outcomes calculated on the basis of the estimation results from the ordered probit models. Figure 2 presents the predicted probabilities of perceiving training possibilities as good by the type of job contract and holding other variables at their mean. By the type of job contract, the predicted probability of having good training possibilities is lowest for involuntary temporary workers, and then for involuntary part-timers and other part-timers. Involuntary temporary workers' probability to perceive their training possibilities as good was around ten percentage points lower compared to other temporary workers and over ten percentages point lower compared to full-time and permanent 
workers. Probability to perceive training possibilities as good has increased for all groups from 1997 to 2008, but the differences between the groups have remained around the same.

Predicted probabilities for participation in the employer-funded training calculated from probit estimation results (figure 3 ) are also lowest for the involuntary temporary and part-time workers and highest for the permanent and full-time workers. Compared to other temporary workers involuntary temporary workers' probability for employer-funded training is around seven percentage points lower. Involuntary part-time workers also have lower probability of employer-funded training compared to other part-time workers. We could not control for the unobserved heterogeneity in our models due to the cross-sectional nature of our data. Booth et al. (2002) found that controlling for unobserved heterogeneity reduced the effects on training incidence only marginally from effects obtained in pooled probit regression estimates.

The results related to the participation in employer-funded training by job contract type are in accordance with results from other empirical studies (e.g. Arulampalan and Booth, 1998; Jonker and de Griep, 1999; Aronsson et al., 2002; Almeida-Santos and Mumford, 2004 ${ }^{8}$ ), which have found that workers in temporary or part-time employment have a lower probability of employerfunded training compared to permanent and full-time workers. They are also in accordance with the human capital approach which predicts that firms or workers might face reduced incentives to provide or accept training depending on who bears the costs (Arulampalan and Booth, 1998). Incentives for training might be low especially in the case of short contracts when also the posttraining period is short over which the investment can be amortised (Arulampalan and Booth, 1998).

Predicted probabilities for good career prospects and opportunities to learn and grow at work by the job contract type are presented in figures 4 and 5. Figure 4 shows that there has been positive development in career prospects across the time in all contract types from year 1997 to year 2008 but the increase in predicted probability to perceive career opportunities as good has been largest among permanent and full-time workers. It is noteworthy that other temporary workers even have a higher probability to perceive their career opportunities as good than full-time and permanent workers. The predicted probability of having good career prospects is lowest for involuntary parttimers, other part-timers and involuntary temporary workers and the differences between these groups are not statistically significant.

\footnotetext{
${ }^{8}$ Majority of these studies have not made difference by the contract motive.
} 
The predicted probabilities for good opportunities to learn and grow at work also show clear differences by the job contract type: other temporary workers and permanent and full-time workers face the largest probabilities and involuntary and other part-time workers the lowest probabilities. The difference between predicted probabilities for involuntary temporary workers and other temporary workers is around 8-9 percentage points. The corresponding difference between other temporary workers and involuntary part-time workers is around 15 percentage points. Again there has been positive development in opportunities to learn and grow at work across the time in all contract types, but the differences have slightly increased between the groups. According to the QWLS from year 2008 irrespective of the job contract type Finnish workers find it more important to have opportunities to learn and grow at work compared to career opportunities. Opportunities to learn and grow at work also exert a significant influence on perceived job satisfaction ${ }^{9}$.

These results show considerable differences between types of temporary and part-time work by the contract preference for the skills development outcomes, and therefore also indicate how important it is to distinguish between types of temporary and part-time work by the contract preference for the job quality outcomes. Our results imply that equal opportunities for skills development for all workers irrespective of the type of employment do not still exist in the Finnish labour market: those working involuntarily in temporary and part-time jobs seem clearly to be in the worst position in this respect. This development can be regarded as worrisome and also against the principles of the EU's flexicurity policy (European Commission, 2007) that emphasise the importance of providing equal opportunities for all workers to learn and get training at work, to update their skills, and to increase their human capital. In the labour market where an increasing number of workers are exposed to uncertainty and possible career interruptions the role of skills development is becoming increasingly important.

Figures 2-5 around here

\section{Job autonomy}

According to Green (2005) job autonomy and discretion over job tasks is also one of the core indicators of job quality and they have impact on the well-being at work. Green (2005) emphasises that according to Sen's capabilities approach (e.g. Sen, 1993) job quality is evaluated through the capabilities that are afforded to workers in the job to achieve well-being and to achieve agency

\footnotetext{
${ }^{9}$ Based on unpublished estimation results using the QWLS from year 2008.
} 
goals. In this approach a high value is attributed to the process of determining and choosing one's activities. Gallie (2008) points out that task discretion has been found critical for people's capacity for self-realization in work, for their personal satisfaction with working life, for their work motivation and commitment with their employer. Job autonomy and discretion over job tasks have also been considered as such features of job that can also help in situations with high and demanding workload (Lehto and Sutela, 2008). It has also been established in empirical studies that job autonomy is positively associated with job satisfaction (e.g. Bauer, 2004). According to Appelbaum et al. (2000) job autonomy exerts a positive impact on workers' trust and intrinsic motivation.

The estimated effects of the job contract type on perceived job autonomy as measured by a sum indicator are presented in Table 3 column 3D. Figure 6 presents the predicted probabilities for good job autonomy by job contract type. The results show that permanent and full-time workers and other temporary workers have highest probabilities of good task discretion. Other part-timers and involuntary temporary and involuntary part-time workers' probabilities are clearly lower. Permanent and full-time workers have around 1.2 times higher predicted probability of good job autonomy than involuntary temporary and part-time workers.

Figure 6 around here

\section{Job insecurity}

One core dimensions of worker wellbeing and job quality is also perceived job security. In the literature job insecurity has been found to associate with perceived stress (e.g. Virtanen et al. 2005) and also reduced levels of job satisfaction (e.g. Sverke and Hellgren, 2002). In the sociological literature the role of job security for social integration has also been emphasised (Paugaum and Chow, 2010). The Finnish QWLS results have showed that perceived insecurity, financial insecurity and difficulty to plan one's future have been found as negative aspects of temporary contracts (e.g. Lehto and Sutela, 2004 \& 2008; Lehto et al., 2006; Kauhanen, 2009).

The estimated effects of the job contract type on perceived job insecurity as measured by the perceived threat of unemployment are presented in Table 4 column 4B. Figure 7 presents the predicted probabilities for the threat of unemployment (i.e. experiences threat of unemployment) by job contract type holding other covariates at their mean. The figure shows that the predicted probability of experiencing the threat of unemployment is by far highest for involuntary temporary 
workers and lowest for permanent and full-time workers. The probability is around 5.5-6.5 times higher for involuntary temporary workers compared to permanent workers and 1.6-1.7 times higher compared to other temporary workers. Involuntary part-time workers face 1.2-1.3 as high threat of unemployment as permanent and full-time employees. The difference between permanent and fulltime workers and other part-timers is not statistically significant. Across time the differences between the job contract types in the perceived unemployment threat have remained quite unchanged.

Figure 7 around here

The QWLS data also includes information on earlier unemployment spells. The data shows that not only the threat of unemployment but also earlier unemployment spells are more common among involuntary and other temporary workers and involuntary part-time workers. Of involuntary temporary workers around $57-81 \%$ had been either unemployed or on temporary layoff during the past five years. The corresponding shares for other temporary workers were around 44-61\% and for involuntary part-time workers $39-44 \%$. The shares are manyfold compared to permanent and fulltime workers and other part-time workers (13-21\% and 9-19\% ${ }^{10}$. As regards job insecurity the polarisation development by the job contract type seems to have continued in Finland.

\section{CONCLUSIONS}

Our results from the Finnish QWLS imply that there are differences in job quality and work wellbeing by the type of job contract. Our results also show the importance of distinguishing between types of temporary and part-time work by the contract preference, i.e. whether these nonstandard employment arrangements are exercised involuntarily or not for the job quality outcomes. Almost without exception involuntary temporary and involuntary part-time workers' experiences of their job quality are weaker with respect to core job quality indicators studied in this paper such as training possibilities, participation in employer-funded training, career possibilities, possibilities to learn and grow at work, job autonomy, and job insecurity compared to permanent and full-time workers. Other temporary workers' perceived job quality with respect to possibilities to learn and grow at work and career prospects are even higher than those of full-time and permanent workers. Aronsson et al. (2002) have shown that in Sweden there are distinct differences

\footnotetext{
${ }^{10}$ Results based on the QWLS data from years 1997, 2003 and 2003. In all job arrangement types the shares of unemployed/on temporary layoff were highest in 1997 and lowest in 2008.
} 
between different sub-groups of temporary workers as regards the possibilities to influence their working conditions. In Aronsson's core-periphery structure (where permanent workers are at the core) project workers and then workers on probationary contract are closest to the permanent workers with their working conditions (such as control, skills development, support). Substitutes occupy the intermediate position and, at the periphery (longest distance from the core) are seasonal and on call workers who have least possibility to influence their working conditions and have also least access to training. In this core/periphery scale it would seem that in the Finnish data other temporary workers would be closer to the core compared to involuntary temporary workers and involuntary part-time workers.

Although there have been positive development in job quality across time in all job contract types, the differences between the groups have remained quite stable. These results imply that equal opportunities for skills development for all workers irrespective of the type of employment do not still exist in the Finnish labour market: those working involuntarily in temporary and part-time jobs are clearly in the worst position in this respect. This can be regarded as worrisome as in the labour market where an increasing number of workers are exposed to uncertainty and possible career interruptions the role of skills development is becoming increasingly important. A clear policy issue is how to prevent these negative consequences related to involuntary atypical employment and promote well-being at work for all worker groups in the changing labour market.

Procedural utility implies that people are likely to obtain utility not only from actual outcomes such as e.g. wages but also from the conditions leading to these outcomes (Frey and Stutzer, 2004). This suggests that job quality and working conditions have also great impact on worker wellbeing. Individuals may experience a higher subjective wellbeing when they are treated in a way they consider to be fair (Frey and Stutzer, 2004). Fair treatment also includes an equal treatment.

\section{REFERENCES}

Almeida-Santos, F. and Mumford, K. (2004), Employee Training and Wage Compression in Britain, IZA Discussion Paper no.1197.

Aronsson, G., Gustafsson, K., \& Dallner, M. (2002), Work environment and health in different types of temporary jobs. European Journal of Work and Organizational Psychology, 11(2), 151-175.

Arulampalan, W. and Booth, A. (1998), Training and labour market flexibility: Is there a trade-off?, The British Journal of Industrial Relations, 36(4), pp.521-536. 
Bauer, T. (2004), High performance workplace practices and job satisfaction: Evidence from Europe, IZA Discussion Paper no.1265.

Bishop, J. H. (1996), What we know about employer-provided training: A review of literature. CAHRS Working Paper 96-09, Cornell University.

Blank, R. (1998), Contingent work in a changing labor market in R. Freeman and P. Gottschalk (eds.), Generating jobs: How to increase demand for less-skilled workers. NY: Russell Sage Foundation, pp. 258294.

Booth, A., Francesconi, M. and Frank, J. (2002), Temporary jobs: stepping stones or dead ends? The Economic Journal Vol.112, No.480, pp. F189-F213.

Buhai, S., Cottini, E. and Westergård-Nielsen, N. (2008), The impact of workplace conditions on firm performance. Tinbergen Institute Discussion Paper TI 2008-077/3.

De Graaf-Zilj, M. (2005), The economic and social consequences of temporary employment: a review of the literature. SEO Discussion Paper. Amsterdam: SEO Economic Research.

European Foundation for Improvement of Living and Working Conditions (2002), Quality of work and employment in Europe issues and challenges, Foundation Paper N.1, February 2002, Luxembourg.

European Foundation for Improvement of Living and Working Conditions (2008), Working conditions of an ageing workforce. Luxembourg.

European Commission (2005), Integrated guidelines for growth and jobs (2005-08). http://europa.eu/ growthand jobs/pdf/COM2005_14_en.pdf.

European Commission (2007), Communication from the Commission to the Council, the European Parliament, the European Economic and Social Committee and the Committee of the Regions. Towards Common Principles of Flexicurity: More and better jobs through flexibility and security. http://ec.europa.eu/employment_social/news/2007/jun/flexicurity_en.pdf.

European Commission (2008), Employment in Europe 2008.

European Commission (2009), Employment in Europe 2009.

Ferrer-i-Carbonell, A. and Frijters, P. (2004), How important is methodology for the estimates of the determinants of happiness?, Economic Journal, vol. 114, no. 7, 641-659.

Frey, B. S. and Stutzer, A. (2002), What can economist learn from happiness research? Journal of Economic Literature, vol. xl, 402-435.

Frey, B. S. and Stutzer, A. (2004), Beyond outcomes: measuring procedural utility. Oxford Economic Papers vol. 57, 90-111.

Gallie, D. (2008), Task discretion and job quality. In D. Gallie (ed.) Employment regimes and quality of work, Oxford University Press, 105-136.

Green, F. (2005), Demanding work - the paradox of job quality in the affluent economy, Princeton University Press.

Isaksson, K.S. and Bellagh, K. (2002), Health problems and quitting among female "temps", European Journal of Work and Organizational Psychology 11(1): 27-45. 
Jonker, N. \& de Grip, A. (1999), Do employees with flexible contracts receive less training? Research Centre for Education and the Labour Market, Faculty of Economics and Business Administration, Maastricht University.

Kalleberg, A., Reskin, B. and Hudson, K. (1999), Bad jobs in America: Standard and nonstandard employment relations and job quality, American Sociological Review Vol.65 no.2, 256-278.

Kalleberg, A. and Vaisey, S. (2005), Pathways to good job: perceived job quality among the machinists in North America, British Journal of Industrial Relations, vol. 43: 431-454.

Kauhanen, M. (2007), Eriarvoistumiskehitys on jatkunut työmarkkinoilla 2000-luvulla. Teoksessa H. Taimio (toim.) (2007): Talouskasvun hedelmät: kuka sai ja kuka jäi ilman, 100-121, Helsinki: TSL.

Kauhanen, M. (2009), Epätyypilliset työsuhteet ja työhyvinvointi. Teoksessa Taimio, H. (toim.), Kurssin muutos: Kestävään kasvuun ja hyvinvointiin, 184-210. Helsinki: TSL.

Krausz, M. (2000), 'Effects of short- and long-term preference for temporary work upon psychological outcomes', International Journal of Manpower 21: 635-47.

Leschke, J. (2007) To what extent are temporary work and part-time work cushioned by different forms of security?, In H. Jørgensen \& P. Madsen (eds.): Flexicurity and Beyond: Finding a new agenda for the European Social Model, Copenhagen: DJØF Publishing, pp. 561-601.

Leschke, J. and Watt, A. (2008), Job quality in Europe, ETUI-REHS WP 2008.07.

Lehto, A.-M. ja Sutela, H. (2004), Uhkia ja mahdollisuuksia. Työolotutkimusten tuloksia 1977-2003. Tilastokeskus, Helsinki.

Lehto, A.-M., Lyly-Yrjänäinen, M. ja Sutela, H. (2006), Pysyvän työn toivossa. Määräaikaisten työsuhteiden käytöstä ja kokemisesta. Työpoliittinen tutkimus 291. Helsinki: Työministeriö.

Lehto, A.-M. ja Sutela, H. (2008), Työolojen kolme vuosikymmentä. Työolotutkimusten tuloksia 1977-2008. Tilastokeskus, Helsinki.

Mincer, J. (1989), Job Training: Costs, Returns and Wage Profiles. NBER Working Paper No. 3208.

Paugam, S. and Zhou, Y. (2010), Job insecurity. In D. Gallie (ed.) Employment regimes and quality of work, Oxford University Press, 137-178.

Royuela, V. and Suriñach, J. (2008), Quality in work and productivity. IAREG Working Paper WP2/05. Universitat de Barcelona.

Sen, A. (1993), Capability and Well-being. In M. Nussbaum \& Amartya S. (eds.), The Quality of Life, Oxford, Clarendon Press, pp. 30-53.

Sverke, M. and Hellgren, T. (2002), The nature of job insecurity: understanding employment uncertainty on the brink of a new millennium, Applied Psychology: An international review 51(1): 23-42.

Virtanen, M., Kivimäki, M., Joensuu, M., Virtanen P., Elovainio M. and Vahtera, J. (2005), Temporary employment and health: a review. International Journal of Epidemiology vol. 34(3), 610-622.

Zelenski, J.M., Murphy, S.A. and Jenkins, D.A. (2008), The happy-productive worker thesis revisited. Journal of Happiness Studies vol 9, 521-537. 


\section{APPENDIX}

Table 1. Characteristics of wage and salary earners by the type of job contract.

Pooled data:

\begin{tabular}{llllll}
\hline & $\begin{array}{l}\text { Involuntary } \\
\text { temporary }\end{array}$ & Other temporary & $\begin{array}{l}\text { Involuntary } \\
\text { part-time }\end{array}$ & Other part-time & $\begin{array}{l}\text { Permanent and } \\
\text { full-time }\end{array}$ \\
\hline Female & 67.4 & 60.2 & 80.6 & 73.9 & 48.4 \\
Age (average) & 35.4 & 32.6 & 39.0 & 41.5 & 42.6 \\
Married & 65.2 & 58.9 & 71.3 & 65.2 & 75.9 \\
Time in working life & 12.2 & 10.2 & 17.6 & 20.1 & 21.9 \\
(average in years) & & & & & 17.4 \\
Primary education & 14.6 & 14.5 & 25.7 & 24.7 & 46.3 \\
Secondary education & 50.9 & 49.2 & 57.0 & 47.9 & 36.4 \\
Tertiary education & 34.5 & 36.2 & 17.3 & 27.4 & 32.8 \\
Public sector & 59.7 & 58.4 & 25.6 & 30.9 & 35.1 \\
Blue-collar worker & 31.1 & 23.0 & 38.4 & 31.4 & 37.3 \\
Lower white-collar worker & 43.0 & 44.8 & 53.6 & 52.2 & 27.6 \\
Upper white-collar worker & 25.9 & 32.1 & 8.0 & 16.3 & \\
\hline
\end{tabular}

Year 1997:

\begin{tabular}{llllll}
\hline & $\begin{array}{l}\text { Involuntary } \\
\text { temporary }\end{array}$ & Other temporary & $\begin{array}{l}\text { Involuntary } \\
\text { part-time }\end{array}$ & Other part-time & $\begin{array}{l}\text { Permanent and } \\
\text { full-time }\end{array}$ \\
\hline Female & 66.1 & 29.3 & 75.0 & 73.0 & 49.3 \\
Age (average) & 34.4 & 27.1 & 38.3 & 37.7 & 41.2 \\
Married & 65.8 & 56.7 & 73.3 & 63.5 & 76.3 \\
Time in working life & 12.8 & 6.5 & 18.6 & 16.0 & 21.2 \\
(average in years) & & & & & 24.0 \\
Primary education & 21.6 & 19.5 & 31.7 & 29.4 & 55.3 \\
Secondary education & 59.1 & 61.0 & 63.3 & 53.2 & 20.7 \\
Tertiary education & 19.3 & 19.5 & 5.0 & 17.4 & 31.4 \\
Public sector & 54.1 & 35.0 & 10.0 & 27.0 & 38.5 \\
Blue-collar worker & 38.9 & 26.8 & 46.7 & 33.3 & 38.6 \\
Lower white-collar worker & 41.8 & 36.6 & 48.3 & 48.4 & 22.9 \\
Upper white-collar worker & 19.3 & 36.6 & 5.0 & & 18.2 \\
\hline
\end{tabular}

Year 2003:

\begin{tabular}{llllll}
\hline & $\begin{array}{l}\text { Involuntary } \\
\text { temporary }\end{array}$ & Other temporary & $\begin{array}{l}\text { Involuntary } \\
\text { part-time }\end{array}$ & Other part-time & $\begin{array}{l}\text { Permanent and } \\
\text { full-time }\end{array}$ \\
\hline Female & 66.1 & 55.4 & 81.6 & 70.6 & 48.2 \\
Age (average) & 35.6 & 31.5 & 38.9 & 42.7 & 42.7 \\
Married & 65.2 & 66.1 & 72.4 & 62.5 & 76.2 \\
Time in working life & 12.2 & 9.4 & 17.3 & 21.3 & 21.8 \\
(average in years) & & & & 26.8 & 17.2 \\
Primary education & 12.2 & 12.3 & 26.5 & 49.6 & 42.5 \\
Secondary education & 45.9 & 44.6 & 51.0 & 23.5 & 40.3 \\
Tertiary education & 41.9 & 43.1 & 22.4 & 40.0 & 34.4 \\
Public sector & 62.7 & 57.3 & 26.2 & 35.3 & 35.7 \\
Blue-collar worker & 27.9 & 20.0 & 40.8 & 49.3 & 36.4 \\
Lower white-collar worker & 43.0 & 52.3 & 51.0 & 15.4 & 27.8 \\
Upper white-collar worker & 29.0 & 26.7 & 8.2 & & \\
\hline
\end{tabular}


Year 2008:

\begin{tabular}{llllll} 
& $\begin{array}{l}\text { Involuntary } \\
\text { temporary }\end{array}$ & Other temporary & $\begin{array}{l}\text { Involuntary } \\
\text { part-time }\end{array}$ & Other part-time & $\begin{array}{l}\text { Permanent and } \\
\text { full-time }\end{array}$ \\
\hline Female & 71.4 & 67.5 & 83.5 & 77.3 & 49.1 \\
Age (average) & 36.3 & 33.9 & 39.5 & 41.9 & 43.4 \\
Married & 66.5 & 57.8 & 68.3 & 68.6 & 75.3 \\
Time in working life & 12.4 & 11.1 & 18.3 & 21.4 & 22.7 \\
(average in years) & & & & 20.6 & 13.2 \\
Primary education & 11.6 & 14.2 & 20.2 & 43.9 & 43.8 \\
Secondary education & 47.6 & 48.4 & 59.5 & 35.5 & 42.9 \\
Tertiary education & 40.8 & 37.3 & 20.2 & 38.4 & 34.4 \\
Public sector & 64.2 & 62.3 & 15.2 & 26.8 & 32.2 \\
Blue-collar worker & 25.2 & 23.2 & 29.1 & 56.8 & 37.3 \\
Lower white-collar worker & 44.7 & 44.4 & 60.8 & 16.4 & 30.5 \\
Upper white-collar worker & 30.1 & 32.6 & 10.1 & & \\
\hline
\end{tabular}

Notes: These groups are mutually exclusive. Therefore workers working at the same time as part-timer in a temporary job are excluded from our analysis.

Table 2. Average scores for job quality indicators by job contract type from pooled data.

\begin{tabular}{|c|c|c|c|c|}
\hline & $\begin{array}{l}\text { Possibilities for } \\
\text { employer-funded } \\
\text { training (scale } 1 \text { to } 3 \text { )* }\end{array}$ & $\begin{array}{l}\text { Participation in } \\
\text { employer-funded } \\
\text { training }(0 / 1)\end{array}$ & $\begin{array}{l}\text { Career opportunities } \\
\text { (scale } 1 \text { to } 3 \text { ) }\end{array}$ & $\begin{array}{l}\text { Possibilities to learn } \\
\text { and grow at work } \\
\text { (scale } 1 \text { to } 3 \text { ) }\end{array}$ \\
\hline permanent + full-time & 2.20 & 0.584 & 1.51 & 2.24 \\
\hline involuntary temporary & 1.98 & 0.398 & 1.47 & 2.21 \\
\hline other temporary & 2.26 & 0.504 & 1.70 & 2.43 \\
\hline involuntary part-time & 1.89 & 0.321 & 1.46 & 1.96 \\
\hline \multirow[t]{2}{*}{ other part-time } & 2.02 & 0.425 & 1.48 & 2.08 \\
\hline & $\begin{array}{l}\text { Job autonomy (sum } \\
\text { indicator, scale } 1 \text { to } 3 \text { ) }\end{array}$ & $\begin{array}{l}\text { Threat of } \\
\text { unemployment }(0 / 1)\end{array}$ & & \\
\hline permanent+ full-time & 2.08 & 0.125 & & \\
\hline involuntary temporary & 1.97 & 0.621 & & \\
\hline other temporary & 2.05 & 0.314 & & \\
\hline involuntary part-time & 1.94 & 0.261 & & \\
\hline other part-time & 1.92 & 0.112 & & \\
\hline
\end{tabular}

Note: Scale 1 to 3 , where $1=$ poor and $3=$ good. These groups are mutually exclusive. Therefore workers working at the same time as part-timer in a temporary job are excluded from our analysis. 
Table 3. Pooled ordered probit estimation results.

\begin{tabular}{lllll}
\hline & $3 \mathrm{~A}$ & $3 \mathrm{~B}$ & $3 \mathrm{C}$ & $3 \mathrm{D}$ \\
\hline & Coefficient & Coefficient & Coefficient & Coefficient \\
\hline Involuntary temporary & $-0.339 * * *$ & $-0.110^{* *}$ & $-0.108^{* *}$ & $-0.166^{* * *}$ \\
& $(0.043)$ & $(0.0275)$ & $(0.026)$ & $(0.026)$ \\
Other temporary & -0.088 & 0.044 & 0.112 & -0.030 \\
& $(0.067)$ & $(0.069)$ & $(0.068)$ & $(0.068)$ \\
Involuntary part-time & $-0.310^{* * *}$ & $-0.145^{*}$ & $-0.297 * * *$ & $-0.158^{* *}$ \\
& $(0.075)$ & $(0.084)$ & $(0.075)$ & $(0.078)$ \\
Other part-time & $-0.263 * * *$ & $-0.110^{* *}$ & $-0.221^{* * *}$ & $-0.211^{* * *}$ \\
& $(0.047)$ & $(0.052)$ & $(0.047)$ & $(0.048)$ \\
\hline Number of obs & 10859 & 10789 & 10864 & 10519 \\
\hline
\end{tabular}

Note: In addition all estimates include gender dummy, age, age-squared, dummy variables for education and socioeconomic status, dummy variable for children under18 years, for firm size, industry and sector, and year dummies. Standard errors are in parenthesis.

$* * *$ : difference significant at $1 \%$ level, **: difference significant at 5\% level, *: difference significant at $10 \%$ level.

$\mathbf{3 A}=$ possibilities for employer-funded training, $3 \mathrm{~B}=$ career opportunities, $3 \mathrm{C}=$ possibilities to learn and grow at work, 3D= job autonomy.

Table 4. Pooled probit estimation results.

\begin{tabular}{lll}
\hline & $4 \mathrm{~A}$ & $4 \mathrm{~B}$ \\
\hline & Coefficient & Coefficient \\
\hline Involuntary temporary & $-0.339 * * *$ & $1.640 * * *$ \\
& $(0.043)$ & $(0.051)$ \\
Other temporary & -0.088 & $0.948 * * *$ \\
& $(0.067)$ & $(0.080)$ \\
Involuntary part-time & $-0.310^{* * *}$ & $0.557 * * *$ \\
& $(0.075)$ & $(0.092)$ \\
Other part-time & $-0.263 * * *$ & 0.080 \\
& $(0.047)$ & $(0.069)$ \\
\hline Number of obs & 10859 & 10945 \\
\hline
\end{tabular}

Note: In addition all estimates include gender dummy, age, age-squared, dummy variables for education and socioeconomic status, for children under18 years, for firm size, industry and sector and year dummies. Standard errors are in parenthesis.

***: difference significant at $1 \%$ level, **: difference significant at 5\% level, *: difference significant at $10 \%$ level.

$4 \mathrm{~A}=$ participation in employer-funded training during past 12 months, $4 \mathrm{~B}=$ threat of unemployment. 
Figure 2. Good possibilities for training by job contract type.

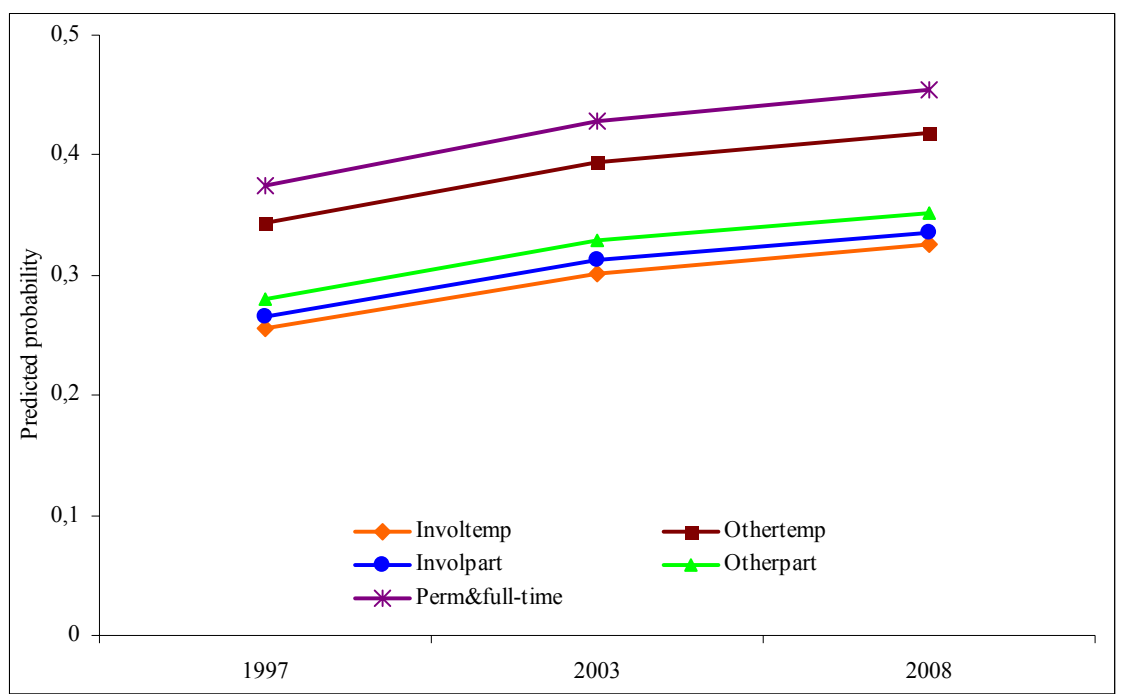

Note: Involtemp=involuntary temporary, Othertemp $=$ other temporary, Involpart= involuntary part-time, Otherpart $=$ other part-time, perm\&full-time $=$ permanent and full-time.

Figure 3. Participation in the employer-funded training by job contract type.

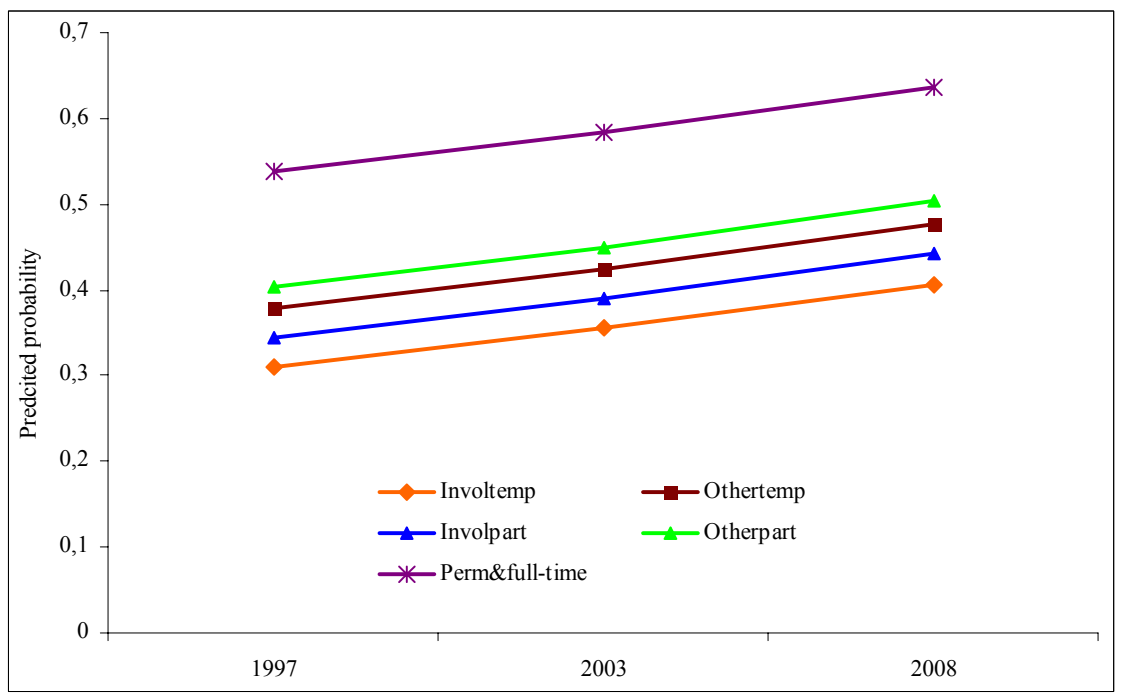


Figure 4. Good career opportunities by job contract type.

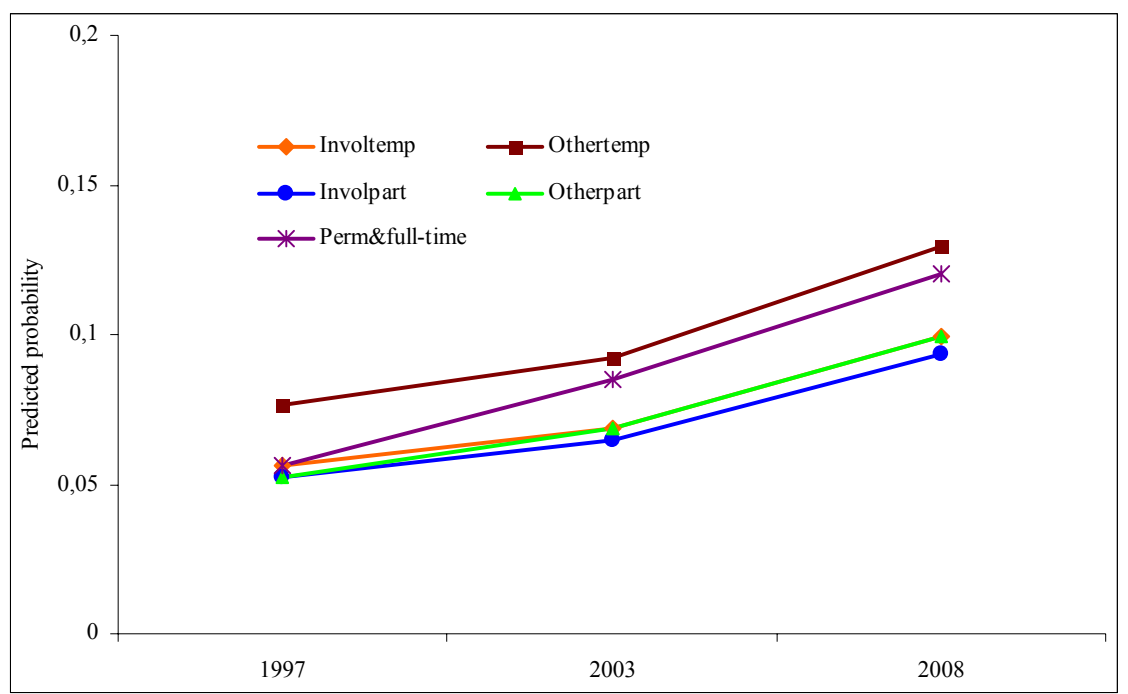

Figure 5. Good opportunities to learn and grow at work by job contract type.

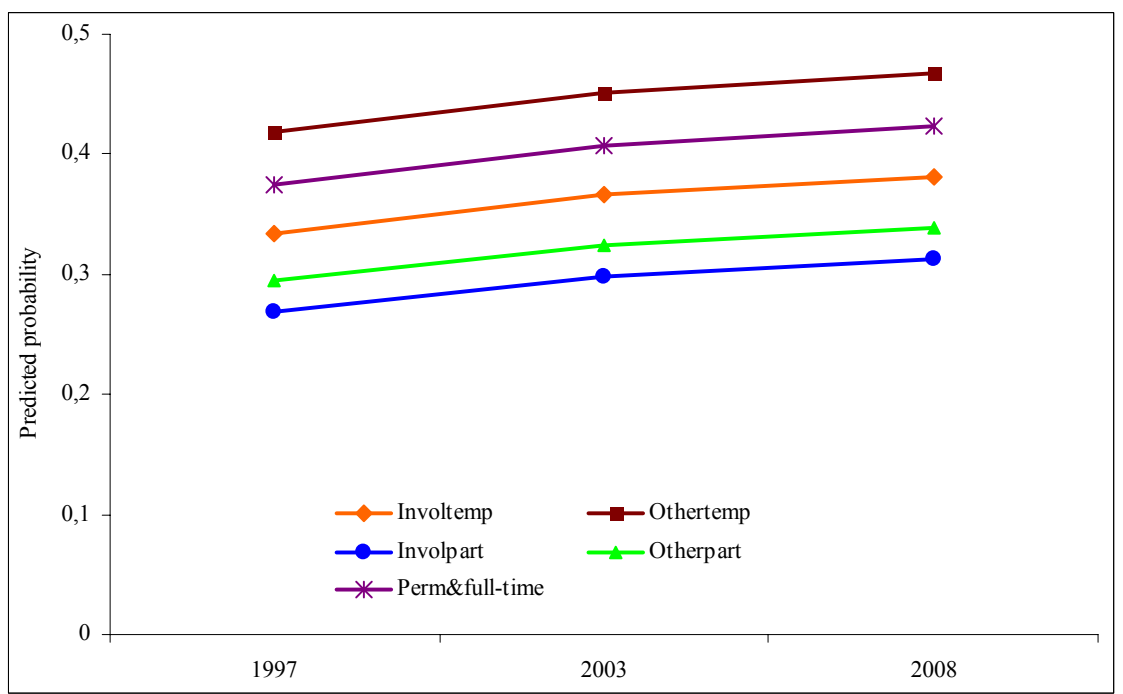


Figure 6. Good job autonomy by job contract type.

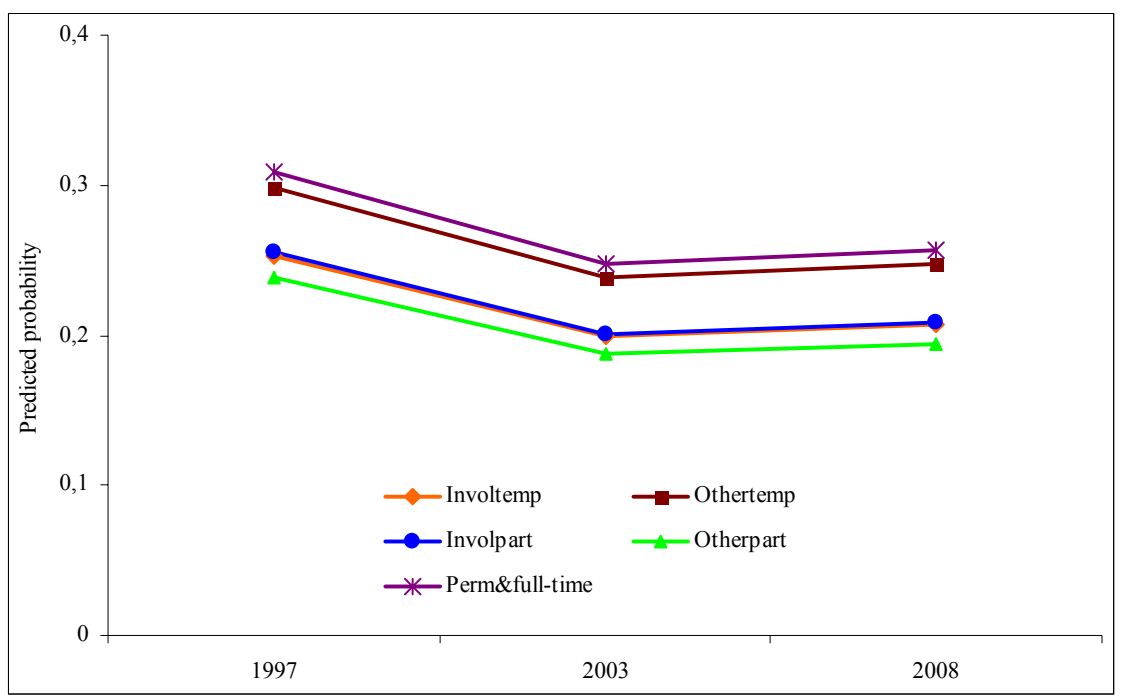

Figure 7. Perceived threat of unemployment by job contract type.

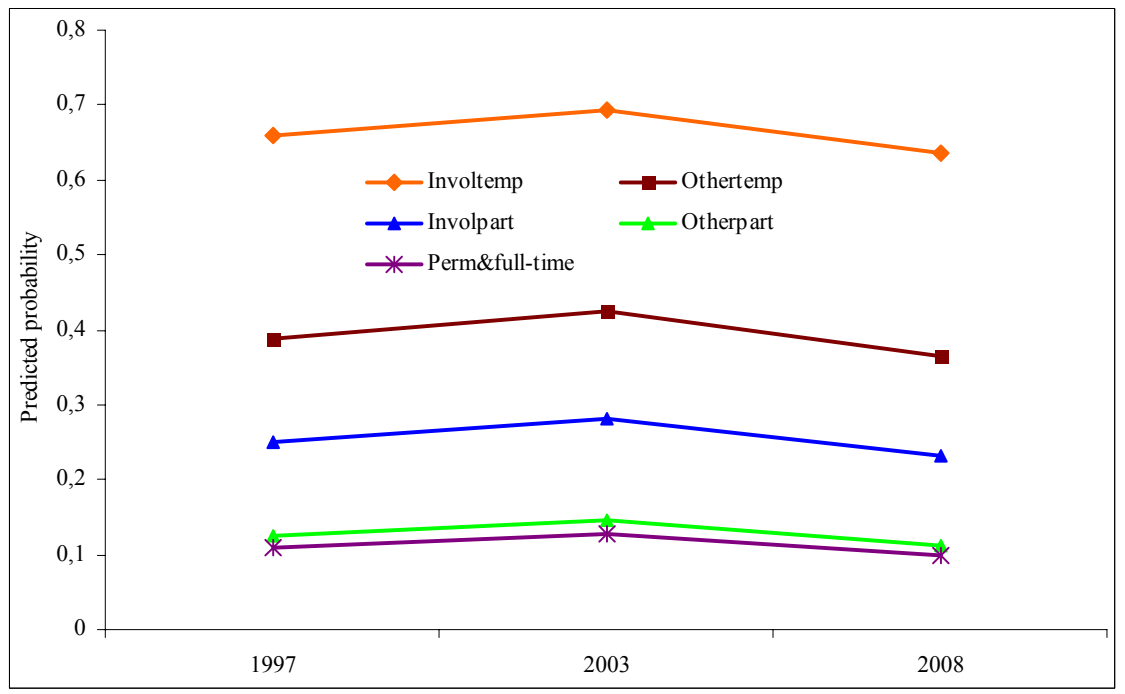

